\title{
Diversified Internship Intention Mode of College Students
}

\author{
Taking College of Politics and Administration as an Example
}

\author{
Dezhi Tong \\ College of Politics and Public Administration \\ Tianjin Normal University \\ Tianjin, China \\ E-mail: tongdezhi@sina.com
}

\begin{abstract}
Internship is of great importance for the education of college students, and most students hold the positive attitude towards internship. In the way of internship, diversified internship is more acceptable for students; from the perspective of internship time, students hope that the college takes the actual needs of different students into account with the combination of independent internship and unified arrangement of the college; As for content, students are more willing to accept the combined internship way of project, survey and post, which means that there is a diversified intention mode in the internship issue of college students.
\end{abstract} Reform

Keywords-College Students; Internship Intention; Survey;

\section{PROPOSAL OF THE ISSUE}

College graduates have to transform their role from students to employees, which cannot be achieved only by the mastery of basic theoretical knowledge at school. Instead, a certain period of internship is required, so that the process of role transform can be more smooth.

In semesters of the internship of college students, different ways are taken by different schools which depend on their own actual situation and development objectives. For example, the Internship Management Method for Undergraduates in Renmin University of China (Revised in December, 2008); the Internship Management Method for Undergraduates in China University of Political Science and Law (the 5th revision in 2005); Internship Management Regulations for Undergraduates in Guangxi University (Revised in September, 2005) and the Internship Management Regulations of Tianjin Normal University. In order to regulate the independent internship of students, correspondent regulations have been made by some schools, for example, the Scattered Internship Management Method for Undergraduates of Beijing University of Technology (Trial in July, 2006) is carried out by Beijing University of Technology.

Through organization for these literatures about management methods, we've got a general understanding of the basic content, mode and time requirements for internship of college students, the relatively common practice is shown below:

1. The rules, regulations and management methods of the internship are developed by the school in a unified way, which are specifically implemented in accordance with the features of majors and actual situation of each college, and often take the training objectives of students as the core;
2. Ways of internship mainly include the unified and centralized internship organized by the college and independent internship organized by students. There are situations about the combination of the two ways as well;

3. The time of internship is usually between the fifth semester and the eighth semester, which is carried out in accordance with the teaching schedule of the college and is controlled within approximately 6 weeks in general;

In order to have a better understanding about the basic attitudes and ideas of students towards internship, we've organized the survey about internship willingness of college students, so as to meet the internship requirements for college students and promote the implementation of the internship work. In order to understand the internship willingness of students in College of Politics and Administration and obtain the sample which can reflect the entire situation with better representativeness, we've adopted the relatively scientific sampling method. Stratified sampling is applied first. Due to the similar quantity of students of each major in the college, we draw 10 boys and ten girls from each class randomly through the computer (there is only one class for each major) as the research objects.

\section{RESULT ANALYSIS}

The survey about internship situation for college students is based on the scientific research methods. We've conducted overall analysis and research on this survey with the application of SPSS for systematical analysis of all data in our survey, so as to obtain the valuable result finally.

(A) Internship Attitude

Through interviewing students of each major and each grade in the College of Politics and Administration, we've known that most students hold a rather positive attitude towards the undergraduate internship, thinking that they can have further contact with the society through internship, which can be seen as a process of further learning as well. Besides, they can have deeper awareness of their own gap and advantages compared with others, so as to make progress in employment. Therefore, students, including freshmen are becoming more and more realistic now. They start to take successful employment as the only purpose in internship with the consideration that the process of internship is also a process of learning. This is largely due to the current sever employment situation, which is also reflected in our questionnaire data about whether undergraduate internship is important for students 
of each grade and major in the College of Politics and Administration.

\begin{tabular}{|c|c|c|c|c|}
\hline \multicolumn{5}{|c|}{ Table1 Significance for Internship } \\
\hline \multirow{4}{*}{} & & Frequency & Percentage & Accumulated percentage \\
\hline \multirow{4}{*}{ Effectiveness } & Extremely important & 146 & 52.9 & 52.9 \\
\cline { 2 - 6 } & Important & 119 & 43.1 & 96.0 \\
\cline { 2 - 6 } & Unimportant & 7 & 2.5 & 98.6 \\
\cline { 2 - 6 } & Extremely unimportant & 2 & 0.7 & 99.3 \\
\cline { 2 - 6 } & No idea & 2 & 0.7 & 100.0 \\
\cline { 2 - 6 } & Total & 276 & 100.0 & \\
\hline
\end{tabular}

As can be seen clearly from the data of Table 1, among the 276 students, $52.9 \%$ and $43.1 \%$ of them consider that internship are "extremely important" and "important" respectively, whose accumulated percentage has reached $96.0 \%$ and is much higher than the percentage of other options. Therefore, it tends to be a common sense that internship for undergraduates during the school days is important, the conclusion of which is also consistent with the conclusion we made through the interview in that school.

(B) Internship Orientation

With increasing number of college graduates in recent years, the problem of employment seems to become more severe and prominent. In 2010, the number of graduates was six times that at the turn of this century, which reached 6.6 million in 2011 and 6.8 million in 2012. During the "12th Five-year Plan" period, the annual urban labor supply of China will reach 24 million, while the annual employment posts is only 9 million, so the gap between annual demand and supply will exceed 10 million. In this case, students will have to face increasingly severe employment problem, and successful employment has become the final objective for many college students whose intention becomes more and more urgent in face of the unsatisfactory employment situation for postgraduates in recent years. Under such realistic circumstance, the employment concept for students has changed greatly as well. They hope to practice more or get more experience through internship, so as to meet their own actual needs. In addition, they hope to improve the employment ability truly through internship.

As has been found through the survey for undergraduates of each grade in the College of Politics and Administration, students are much targeted in answering their practical orientation problems. Among all the options, the top three selections include getting experience, integrating theories and practice, and contacting society (see Table 2). They do not really care about the payment.

Table2 Internship Orientation (Multi-choice)

\begin{tabular}{|c|c|c|c|c|c|}
\hline & $\begin{array}{l}\text { Integrating } \\
\text { theories and } \\
\text { practice }\end{array}$ & $\begin{array}{l}\text { Getting } \\
\text { ex perience }\end{array}$ & $\begin{array}{l}\text { Obtaining } \\
\text { remuneration }\end{array}$ & $\begin{array}{l}\text { Contactin } \\
\text { g society }\end{array}$ & Othet \\
\hline Frequency & 163 & 220 & 49 & 186 & 3 \\
\hline Percentage (\%) & 59.0 & 79. 7 & 17.8 & 67.4 & 1.1 \\
\hline
\end{tabular}

This result is also in line with the entire employment context of the society. The main purpose of internship for students is not to obtain remuneration, but to improve their own ability, so as to accumulate experience for the successful employment and be more involved in social activities.

(C) Internship Time

Time for internship varies in different schools, but it mostly is between the third semester and the eighth semester, that is, between the first semester of Grade 2 and the second semester of Grade 4. It is specifically in accordance with the teaching schedule of the college. Generally, the period is controlled within 6 weeks. It is regulated in the sixth article of "Specialty Practice Management Method for Undergraduates in Renmin University of China" (Revised in December, 2008) that "the internship time for undergraduates shall be at discretion of the colleges on the basis of the teaching program regulations, which is generally in the sixth or seventh semester with a period of no less than 4 weeks"; It is regulated in the second article of "Practice Teaching Management Regulations for Undergraduates in Guangxi University" (Revised in September, 2005) that the internship time "can be during the semester period or during winter and summer holidays"; We've checked the "Specialty Practice Management Regulations of Tianjin Normal University" and found the fifth article about duties of colleges has regulated that "the specialty practice outline and internship plan shall be organized and developed, including the selection of time and place; the internship plan implementation shall be organized, including the implementation of time and place". It can be seen that the colleges are the main body of internship in that school, which provides more autonomy for them to conduct practical internship activities in accordance with their own major features and teaching arrangements.

We've interviewed students from various majors and grades in Tianjin Normal University about the issue of internship time, and have collected different opinions with the integration of their own actual situation, which mainly includes the following aspects:

1. Internship time shall be extended and be controlled within half a semester or even longer time. The current internship time provided by schools is too short, which prevents students from learning more in-depth knowledge. Besides, what they've learnt through the internship is rather superficial and simple. Through the extension of internship time, students will be able to perform better in work departments and learn more things after the longterm internship.

2. Appropriate time shall be selected for internship. Different students have set different paths for their life with different objectives currently. Some would like to study hard and go to the college they like in the future for further study; some would like to take various vocational skill exams, get some requisite professional credentials, and find relatively satisfying jobs; others prefer to take the civil service exam and become a member of the government departments... It is exactly because of such reasons, students who want to take the postgraduate entrance exam would like to take the internship after the completion of the exam, while those want to work and those taking the civil service exam hope the school will advance the internship time as early as possible. This phenomenon indicates that the internship management methods for undergraduates carried out by schools at 
present are contradictory with the actual need of students, and the unified internship way adopted by schools (colleges) cannot satisfy the diversified internship needs of students apparently.

3. Students hope to carry out internship for many times during the school days instead of doing it at one time. It can be conducted in different semesters and on holidays preferably from freshmen, so that students can aware of the severity and urgency of employment at the beginning of colleges, and they can focus more on taking theoretical classes with the awareness of their own insufficiency and weaknesses during practice. In this way, their study can be improved in the follow-up phases.

It is discovered in the questionnaire process for students of the College of Politics and Administration that students prefer to take internship in the junior year and on holidays, the effective percentage of which is $35.9 \%$ and $40.2 \%$ respectively. I think that students who would like to take internship in the junior year hope to save more time for writing papers, searching jobs, reviewing postgraduate entrance exams, and taking civil service exams. Those who prefer to take internship on holidays consider that they can make use of the long holiday time to take internship without interfering the class time or worrying about the course load, so that they can be more devoted to the internship.

(D) Internship Mode

The integrative way of centralized internship and decentralized internship is widely applied by schools, for the application of merely the former one could not meet the diversified internship needs of students now. Students are paying more attention to the employment issue of undergraduates with the connection of internship and future work. They hope to increase ability and accumulate experience through the internship not just for the purpose of completing teaching tasks as a "routine". In order to meet such requirements, measures have been taken by schools through the modification of the internship management method documents again and again. As the employment situation gets more severe, it becomes especially important for schools to find the appropriate internship mode in line with their own school characteristics.

Our survey for the College of Politics and Administration is also in line with our common judgment. Students start to care more about their ability improvement, practical application of theoretical knowledge, and integration of theories and practice through internship rather than the credit. So the key point for concern has been changed essentially from the purely obtaining of degree and diploma to the realization of successful employment.

1. The attitude of students towards the unified internship organization by the college with everyone's involvement

As can be seen from the answer to the question that "are you agree with unified internship by the college with everyone's involvement" in our questionnaire, students are rather acceptable about this mode, because 173 students have made the response of "agree" and "strongly agree" with the accumulated percentage of $62.7 \%$. However, 92 students have made the response of "disagree" and "strongly disagree", accounting for $33.3 \%$. This indicates that students are not so satisfied with this internship mode, which seems to be unable to keep up with students' demands and have imposed some restrictions to the selffulfillment of students.

2. The internship mode acceptable by students

On the one hand, through the field interview with students, we've discovered that the complete independent internship is considered to be risky by students. For example, it is difficult for students from other regions to find an internship department related to their majors, and the quality of the internship is hard to be guaranteed; On the other hand, students think that the internship totally organized by the college can only meet the needs of most students' not all of them. Besides, its restriction in the implementation process seems to be greater in the increasingly sever employment background. In this case, it has become a more realistic choice for most colleges at present to give full play to the human resources accumulated by the college for many years in the internship process, combine the actual demands of students, and carry out the internship mode of "integrating independent internship and the internship organized by the college".

It shows the same result in our survey to the College of Politics and Administration. It has been found through the survey that the number of students hoping to carry out "integration of independent internship and the internship organized by the college" has accounted for most of the whole respondents at $89.1 \%$. It can be seen that most students are relatively agreeable to this mode of internship, which can both guarantee the internship quality and ensure the diversified internship needs of students.

(E) Internship Content

After the internship time and internship mode are surveyed, another important aspect is undoubtedly the internship content, which is commonly referred to as "when to take the internship, how to carry out the internship and what to do in the internship". This could reflect the actual needs of students greatly and is in correlation with the development of students in the future. Those hoping to conduct further study would like the college to provide the project topic for the completion of the relevant thesis or the writing of field survey report; those hoping to realize successful employment would like to practice basic skills hard in the internship department to prepare for their future career; while other students think that the actual situation of the major shall be integrated with the internship content for better settings.

We've found through the survey for students from the College of Politics and Administration that the frequency of "participating in field survey and submitting the survey report" is 118, the frequency of "applying for internship project and identifying by the college" is 53 , the frequency of "deepening the study and practice in actual work developments" is 236 , the frequency of "providing project, expenditure and guidance by the college" is 103 , and the frequency of "others" is 0 . As can be seen from the result, most students would like to take the internship mode of "deepening the study and practice in actual work developments", "participating in field survey and submitting the survey report" and "providing project, expenditure and guidance by the college" in sequence. As 
for the specific reason causing such differences (see Table 3), we'll clarify it in the follow-up analysis.

Table 3 which internship mode do you think is better (multi-choice)

\begin{tabular}{|c|c|c|c|c|c|}
\hline & $\begin{array}{l}\text { Participatin } \\
\mathrm{g} \text { in field } \\
\text { survey and } \\
\text { submitting } \\
\text { the eurvey } \\
\text { repurt }\end{array}$ & $\begin{array}{l}\text { Applying } \\
\text { for } \\
\text { internship } \\
\text { project and } \\
\text { identifying } \\
\text { by the } \\
\text { college }\end{array}$ & $\begin{array}{l}\text { Deepening } \\
\text { the study } \\
\text { and practice } \\
\text { in actual } \\
\text { work } \\
\text { develupruen } \\
\text { ts }\end{array}$ & $\begin{array}{l}\text { Providing } \\
\text { project, } \\
\text { ex penditure } \\
\text { and } \\
\text { guidance by } \\
\text { the cullege }\end{array}$ & Others \\
\hline Frequency & 118 & 53 & 236 & 103 & 0 \\
\hline $\begin{array}{l}\text { Percentage } \\
(\%)\end{array}$ & $42.8 \%$ & $19.2 \%$ & 85.58 & 37.38 & $0.0 \%$ \\
\hline
\end{tabular}

\section{CONCLUSION AND SUGGESTION}

Through the survey, we've found that college undergraduates own the common awareness of the internship value. The number of the students believing that internship is very important and important has accounted for $96 \%$. So the internship work for college students shall be further strengthened. As can be seen, the internship work for college students is not only an integral part of their theoretical training, but also has earned the recognition of most students. Therefore, it is with great realistic significance to further strengthen the internship work of college students.

However, there is a diversified trend for college students in aspects of the internship time, internship mode and internship content, thus forming the diversified intention modes of internship by college students.

1. The time of internship is with the diversified tendency: There is little correlation with the number of students choosing to take the internship in junior year, senior year and on holidays, while that choosing the holiday internship has exceeded those choosing internship in the senior year.

2. The mode of internship is with the diversified tendency: there are few students choosing complete independent internship or the internship completely organized by the college, the proportion of which is far smaller than that taking the integrative way of the above two. Nearly $90 \%$ students hope to conduct the integration mode of unified internship and independent internship.

3. As for the content of internship, most students hope to go deep to the actual work departments for internship, which in turn arouses the diversified tendency of the internship mode. Two situations of internship project application by students and internship undertaking in actual work departments by students are relatively prevalent.
It is believed by us that internship is not only a matter for schools, colleges and teachers, but a concern for students. Therefore, the optimum internship mode shall be based on the internship intention and idea of students. It is exactly based on such fact and awareness that ways of diversified internship for college students have been put forward.

First, diversification of the internship time. The traditional unified arrangement for internship in the junior or senior year shall be replaced with three internship modes which integrate the internship in junior year, senior year and on holidays for junior and senior students.

Second, diversification of the organization mode. The actual needs of different students shall be taken into account in relation to the internship time arranged by the college, and the integration way of scattered selfdominated internship time by students and the internship way based on unified courses or teaching plans of the college shall be taken;

Third, diversification of the internship content. Projects and guidance shall be provided to students by the college, so that students can complete the internship independently; Students can also participate in the field research with the completion of survey report of certain project under the leadership of teachers from the college; Some internship posts can be provided by the college for students who shall compete for them, which could not only train the adaptability of students to the social competition, but also allow them to get the internship posts they like as a relatively satisfactory mode.

\section{REFERENCES}

[1] Feng Xiaotian: "Sociological Research Methods", Beijing: China Renmin University Press, 2009 edition.

[2] Li Hongbin: "60\% Practitioners Want to Work in State-owned Enterprises by Survey", contained in "Guangming Daily" June 28th, 2012.

[3] Feng Lei, Qiu Yue: "Expanding Employment: Resolve the Worldclass Problem", contained in "Guangming Daily" August 17th, 2012. http://edu.people.com.cn/GB/n/2012/1019/c105319321057.html

[4] Xinhua Network: "How to Face the Campus Recruitment Peak by College Students on Windy Days", October 19th 2012. http://edu.people.com.cn/GB/n/2012/1019/c1053-19321057.html.

[5] Zhu Chongshi, Chen Zhenming: "Chinese Public Policy", Beijing: China Renmin University Press, in 2009.

[6] Edward A. Holdaway, Neil A. Johnson, Eugene W. Ratsoy, David Friesen, The Value of an Internship Program for Beginning Teachers, Educational Evaluation and Policy Analysis, Vol. 16, No. 2, 1994, p.205.

[7] Andrea Varricchio, Service-Learning at All Levels: From Field Trips to Internships, Hispania, Vol. 89, No. 1, 2006, p.161.

[8] Jeanne S. Steffes, Creating Powerful Learning Environments: Beyond the Classroom, Change, Vol. 36, No. 3 2004, p.46.

[9] Jack Wilson, Internships, Math Horizons, Vol. 6, No. 2, 1998, p.13.

[10] D. S. Chauhan, Education for Public Service: Managing Internship Programs, State \& Local Government Review, Vol. 10, No. 3, 1978, p.100 